ISLAMIC BANKING: Jurnal Pemikiran dan Pengembangan Perbankan Syariah, Volume 7 Nomor 1 Edisi Agustus 2021

\title{
PENGARUH BOPO, NPF, ROA DAN INFLASI TERHADAP ASET PERBANKAN SYARIAH DI INDONESIA
}

\author{
Annisa Millania \\ Mahasiswa Fakultas Agama Islam, Universitas Ahmad Dahlan \\ Email: annisa1800032158@webmail.uad.ac.id \\ Rofiul Wahyudi \\ Fakultas Agama Islam, Universitas Ahmad Dahlan \\ Email: rofiul.wahyudi@pbs.uad.ac.id \\ Ferry Khusnul Mubarok \\ Fakultas Ekonomi dan Bisnis Islam, UIN Walisongo Semarang \\ Email: ferrykhusnulmubarok@walisongo.ac.id \\ Julia Noermawati Eka Satyarini \\ Fakultas Agama Islam, Universitas Muhammadiyah Yogyakarta \\ Email: julia.noermawati@fai.umy.ac.id
}

\begin{abstract}
The growth of Islamic banking assets in Indonesia has experienced a very significant growth. The purpose of this study is to analyze the internal and external factors that influence this growth. This research method uses a quantitative design with a causal approach. Internal data sources use Islamic bank financial reports for the 2016-2020 period and external data, namely inflation. The sampling technique was determined by purposive sampling method, namely 7 Islamic Commercial Banks. The results showed that the internal factors NPF and ROA had no significant effect on assets. In contrast, BOPO has a significant effect on assets. External factors, inflation have a significant effect on Islamic banking assets.
\end{abstract}

Keywords: Islamic Bank, BOPO, ROA, $N P F$, Inflation

\begin{abstract}
Abstrak
Pertumbuhan aset perbankan syariah di Indonesia mengalami pertumbuhan yang sangat signifikan. Tujuan dari penelitian ini adalah untuk menganalisis faktor internal dan eksternal yang mempengaruhi pertumbuhan tersebut. Metode penelitian ini menggunakan desain kuantitatif dengan pendekatan kausal. Sumber data internal menggunakan laporan keuangan bank syariah periode 2016-2020 dan data eksternal yaitu inflasi. Teknik pengambilan sampel ditentukan dengan metode purposive sampling yaitu 7 Bank Umum Syariah. Hasil penelitian menunjukkan bahwa faktor internal NPF dan ROA tidak berpengaruh signifikan terhadap aset. Sebaliknya, BOPO berpengaruh signifikan terhadap aset. Faktor eksternal, inflasi berpengaruh signifikan terhadap aset perbankan syariah.
\end{abstract}

Kata kunci: Bank Umum Syariah, BOPO, ROA, NPF, Inflasi 
136 | Annisa Millania, et.al, PENGARUH BOPO, NPF, ROA DAN INFLASI TERHADAP ASET.......

\section{Dasar Pemikiran}

Perkembangan awal perbankan syariah direspon cepat oleh pemerintah dengan menggeluarkan UU No. 7 Tahun 1992. Menurut Shandy Utama (2018) dan terdapat pasal yang berbunyi "bank dengan sistem bagi hasil”. Pada tahun 1998 undang-undang yang berkaitan dengan perbankan syariah disempurnakan dan lahirlah UU No. 10 Tahun 1998 yang mana dalam undang-undang tersebut menegaskan bahwa terdapat dua sistem perbankan di Indonesia yaitu perbankan konvensional dan perbankan syariah (Undang Undang RI 1998). Setelah itu perbankan syariah mulai dikenal oleh masyarakat luas dan mulai bermunculan lembaga-lembaga keuangan berbasis syariah. Menurut Megasuri \& Sari (2018) selaras dengan munculnya banyak lembaga keuangan syariah (LKS) berpengaruh langsung terhadap total aset secara keseluruhan dari keuangan syariah itu sendiri. Total aset merupakan bentuk kontribusi dari perbankan terhadap perbankan nasional. Mengingat jumlah penduduk yang memeluk agama Islam pada saat ini mencapai $87.18 \%$ dari jumlah keseluruhan penduduk di Indonesia (BPS 2010). Sudah sepatutunya perkembangan aset perbankan syariah juga akan mengalami pertumbuhan seiring dengan kebutuhan dari masyarakat akan jasa perbankan syariah itu sendiri.

\section{Tabel 1}

Pertumbuhan aset perbankan syariah (2016- 2020)

(Dalam Miliar rupiah)

\begin{tabular}{|c|c|c|c|c|c|c|}
\hline Indikator & & 2016 & 2017 & 2018 & 2019 & 2020 \\
\hline Aset Bank Syariah & & 356.504 & 424.181 & 477.327 & 524.564 & 529.063 \\
\hline Aset Bank Umum & & 6.729 .799 & 7.387 .634 & 7.913 .491 & 8.562 .974 & 8.725 .913 \\
\hline $\begin{array}{l}\text { Presentase Aset } \\
\text { Syariah }\end{array}$ & Bank & $5297 \%$ & $5,74 \%$ & $6,03 \%$ & $6126 \%$ & $6,06 \%$ \\
\hline
\end{tabular}

Sumber : Otoritas Jasa Keuangan (OJK) 2020

Berdasarkan data di atas dapat diketahui bahwa pertembuhan aset perbankan syariah ini mengalami kenaikan meskipun tidak sebanding dengan pertumbuhan aset perbankan konvensional. Terdapat beberapa faktor yang mempengaruhi besarnya aset suatu perbankan seperti Inflasi, Biaya Operasional Terhadap Pendapatan Operasional 
ISLAMIC BANKING: Jurnal Pemikiran dan Pengembangan Perbankan Syariah, Volume 7 Nomor 1 Edisi Agustus 2021

(BOPO), Non Perfoming Financing (NPF), dan Return of Assets (ROA), dan sebagainya.

Beberapa penelitian telah dilakukan tentang pengaruh internal terhadap eksternal bank syariah. Penelitian fathurrahman dan sari (2020) menganalisis faktor yang mempengaruhi total aset perbankan syariah. penelitian ini menggunakan pendekatan error correction model (ecm) dengan data sekunder yang meliputi dana pihak ketiga (dpk), fdr, gdp, dan inflasi. sampel pada penelitian merupakan data yang diperoleh dari website otoritas jasa keuangan (OJK) dan pusat statistik dalam rentang waktu 20152018. berdasarkan riset yang dilakukan diperoleh kesimpulan bahwa inflasi dalam jangka panjang memiliki dampak positif dan tidak signifikan terhadap aset perbankan syariah. Penelitian lain yang dilakukan wahyudi (2020) yang menguji variabel internal terhadap variabel eksternal. Metode penelitian dengan jenis deskriptif kuantitatif yang menggunakan data sekunder publikasi laporan keuangan pada triwulan I tahun 2020 dari 11 Bank Umum Syariah (BUS) di Indonesia sebagai sampel. Hasil penelitian menunjukkan secara bersama CAR, FDR, NPF, BOPO dan Inflasi memiliki dampak terhadap profitabilitas bank syariah.

Raharjo et al. (2020) melakukan uji pengaruh CAR, NPF, BOPO, dan Inflasi terhadap profitabilitas (ROA) perbankan syariah. Penelitian ini menggunakan data sekunder periode 2014-2018 dengan sampel sebanyak 8 BUS. Teknik analisis data menggunakan linier berganda. Hasil penelitian menunjukkan bahwa variabel BOPO dan Inflasi berpengaruh terhadap ROA sedangkan variabel CAR dan NPF tidak berpengaruh terhadap ROA. Koto (2020) melakukan penelitian terhadap pertumbuhan aset Bank Pembiayaan Rakyat Syariah (BPRS) di Indonesia dengan desain kuantitatif serta menggunkan data sekunder, yaitu laporan keuangan BPRS pada periode 2015-2019 di situs resmi Badan Pusat Statistik (BPS) dan OJK. Hasil penelitian menunjukkan bahwa inflasi dan NPF berpengaruh signifikan sementara ROA tidak berpengaruh signifikan terhadap pertumbuhan aset BPRS. Indura dkk., (2019) telah melakukan penelitian dengan menganalisis variabel internal dan eksternal terhadap pertumbuhan aset bank syariah. Metode analisis data yang digunakan adalah regresi linier berganda untuk menganalisis pengaruh variabel NPF, ROA, FDR, CAR, BOPO, inflasi, pertumbuhan 
ekonomi, dan BI rate terhadap pertumbuhan aset bank syariah di Indonesia. temuanya menjelaskan bahwa semua variabel observasi tidak memiliki dampak terhadap pertumbuhan aset bank syariah di Indonesia.

Oktavianti and Nanda (2019)melakukan penelitian terkait Pengaruh CAR, NPF, BOPO, Inflasi, Produk Domestik Bruto dan Suku Bunga BI Terhadap Pertumbuhan Perbankan Syariah. Penelitian tersebut berdesain kuantitatif dengan menggunakan data sekunder yang berasal dari 11 laporan keuangan BUS periode 2013-2017 sebagai sampel. Hasil penelitian menunjukkan bahwa NPF tidak berpengaruh secara signifikan sementara BOPO berpengaruh negatif signifikan terhadap pertumbuhan perbankan syariah. Penelitian lain yang dilakukan Alawiyah (2019) yang berdesain kuantitatif dengan metode kausal menggunakan data sekunder laporan keuangan tahunan 8 BUS yang menjadi sampel penelitian pada tahun 2014-2018. Temuannya yang meneliti pengaruh variabel NPF, FDR, ROA, Pembiayaan terhadap pertumbuhan aset perbankan syariah menyatakan bahwa beberapa variabel tidak berpengaruh signifikan terhadap aset perbankan Syariah seperti FDR dan pembiayaan, sedangkan NPF dan ROA berpengaruh signifikan terhadap pertumbuhan aset bank syariah. Dhiba dan Esya (2019) meneliti NPF, BOPO, GDP dan SBIS menggunakan data sekunder statistik perbankan syariah periode tahun 2012-2016 dengan purposive sampling sebagai metode pengambilan sampel. Temuannya menyatakan bahwa BOPO dan GDP dalam rentang jangka pendek dan jangka panjang berpengaruh positif tidak signifikan, variabel NPF dalam jangka pendek mempunyai hubungan negatif signifikan sedangkan dalam jangka panjang mempunyai hubungan yang negatif tidak signifikan. Sedangkan pada variabel SBIS menunjukkan dalam jangka pendek mempunyai hubungan positif signifikan sedangkan dalam jangka panjang positif tidak signifikan terhadap pertumbuhan aset perbankan syariah di Indonesia.

Penelitian yang dilakukan Syah (2018) tentang faktor internal dan faktor eksternal yang mempengaruhi profitabilitas Bank Syariah. Metode penelitian untuk menjawab rumusan masalah penelitian menggunakan uji statistik Statistik, Uji-F, Uji-T, Koefisien Korelasi, Koefisien Determinasi dan Regresi Linier. Sumber data penelitian yaitu sekunder selama 2012-2017 pada Bank Umum Syariah Indonesia. Hasil penelitian 
ISLAMIC BANKING: Jurnal Pemikiran dan Pengembangan Perbankan Syariah, Volume 7 Nomor 1 Edisi Agustus 2021

menunjukkan bahwa BI rate, NPF dan BOPO berpengaruh negatif signifikan, sedangkan variabel Inflasi menunjukkan pengaruh negatif tetapi tidak signifikan. Beberapa penelitian sebelumnya umumnya masih menggunakan data dari perbankan syariah pada masa lampau. Sementara pada penelitian yang dilakukan Alawiyah (2019) menggunakan data terbaru, namun dalam penelitian ini tidak menjelaskan dampak yang terjadi dari faktor eksternal terhadap aset perbankan syariah. Selain itu, hasil penelitianpenelitian sebelumnya menunjukkan hasil yang berbeda-beda sehingga diperlukan investigasi lanjutan. Secara makro, investigasi tetang kinerja internal terhadap eksternal masih relevan untuk dilakukan penelitian karena kondisi lingkungan ekonomi domestik dan global akan mempengaruhi performance-nya. Sehingga, penting penelitian ini untuk dilakukan sebagai upaya menjaga tingkat kepercayaan stakeholder.

\section{Kerangka Pemikiran Teoritis}

\section{Inflasi Terhadap Aset}

Inflasi merupakan kemerosotan nilai mata uang (KBBI) yang dapat berpengaruh buruk pada perekonomian (Akbar 2016). Bagi sebuah bank inflasi berpengaruh terhadap penambahan biaya operasional sehingga dapat merugikan bank. Ketika nilai inflasi tinggi menyebabkan tingkat konsumsi dikalangan masyarakat menurun (Megasuri and Sari 2018), sehingga permintaan akan layanan produk bank syariah juga menurun. Hal ini berpotensi mempengaruhi total aset dari perbankan syariah. Penelitian sebelumnya telah menunjukkan adanya hubungan positif dan sebaliknya inflasi terhadap aset bank seperti (Alawiyah 2019; Dalimunthe dan Lestari 2019; Aisyah 2018; Caglayan and Xu 2016; Mawardi 2016; Tolulope and Oyeyinka 2014).

Berdasarkan uraian diatas dapat dirumuskan hipotesisi yaitu:

H0: Inflasi berpengaruh negatif dan signifikan terhadap aset perbankan syariah

H1: Inflasi berpengaruh positif dan signifikan terhadap aset perbankan syariah

BOPO Terhadap Aset

BOPO merupakan rasio yang digunakan suatu bank untuk melihat efisiensi dari sebuah perbankan. Efisiensi dilihat dari perbandingan antara biaya oprasional dan pendapaan oprasional. Semakin kecil rasio BOPO menunjukkan semakin efisien sebuah perbankan dalam mengeluarkan biaya oprasionalnya (Argarina and Kamaliah 2016). 
Artinya bank dapat mengelola keuangan nya dengan baik, sehingga total aset perbankan syariah dapat terkendali. Penelitian sebelumnya menunjukkan adanya hubungan positif dan sebaliknya seperti (Sofie et al. 2020; Wahyudi 2020; Oktavianti and Nanda 2019; Yundi 2018; Puji Wiyati, M. Yusuf 2016; Chou and Buchdadi 2016). Dengan demikian dapat dirumuskan hipotesis yaitu :

$\mathrm{H}_{0}$ : BOPO berpengaruh negatif dan signifikan terhadap aset perbankan syariah.

$\mathrm{H}_{1}$ : BOPO berpengaruh positif dan signifikan terhadap aset perbankan syariah.

\section{NPF Terhadap Aset}

NPF merupakan pembiayaan yang mana dalam pelaksanaan oprasionalnya belum mencapai target yang diinginkan oleh pihak bank. Rasio NPF ini harus diatasi dengan baik, karena hal ini merupakan tolak ukur dari kesehatan sebuah bank (Vanni and Rokhman 2017). Semakin tinggi rasio NPF berarti bank tidak mampu melakukan manajerial dengan baik, sehigga kepercayaan masyarakat tehadap bank berkurang (wasiaturrahma et al. 2020). Yang artinya hal tersebut dapat mengurangi produktifitas bank dan dapat mempengaruhi total pendapatan dari pembiayaan (Supriani and Sudarsono 2018) sehinga dapat berpengaruh terhadap total aset yang dimiliki perbankan syariah. Penelitian sebelumnya menunjukkan adanya hubungan positif dan sebaliknya seperti (Alawiyah 2019; Oktavianti and Nanda 2019; Supriani and Sudarsono 2018). Maka berdasarkan uraian tersebut dapat dirumuskan sebuah hipotesis yaitu :

$\mathrm{H}_{0}$ : NPF berpengaruh negatif dan signifikan terhadap aset bank syariah.

$\mathrm{H}_{1}$ : NPF berpengaruh positif dan signifikan terhadap aset bank syariah.

\section{ROA Terhadap Aset}

ROA merupakan rasio yang menunjukkan kemampuan bank dalam memperoleh profit atau laba. Besaran nilai rasio ROA berbanding lurus dengan total pembiayan pada perbankan syariah (Bakti 2017). Sehingga semakin tinggi nilai ROA pada suatu bank dapat meningkatkan keuntungan yang dimiliki bank (Hijriyani and Setiawan 2017) yang artinya dapat mempengaruhi besaran aset pada perbankan syariah. Penelitian sebelumnya menunjukkan adanya hubungan positif dan sebaliknya seperti (Ardana 2018; Datta and Al Mahmud 2018; Tri Wahyuningsih, Abrar Oemar 2017; Said and Ali 2016). Dengan demikian hipotesis dapat dirumuskan sebagai berikut : 
ISLAMIC BANKING: Jurnal Pemikiran dan Pengembangan Perbankan Syariah, Volume 7 Nomor 1 Edisi Agustus 2021

$\mathrm{H}_{0}$ : ROA berpengaruh positif dan signifikan terhadap aset perbankan syariah.

$\mathrm{H}_{1}$ : ROA berpengaruh negatif dan signifikan terhadap aset perbankan syariah.

\section{METODE PENELITIAN}

Jenis penelitian ini adalah Kuantitatif dengan pendekatan asosiatif untuk mencari hubungan antara variabel depeden terhadap variabel independen. Populasi pada penelitian ini yaitu seluruh Bank Umum Syariah (BUS) di Indonesia yang beroperasi pada tahun 2016-2020. Penelitian ini menggunkan data sekunder dimana sampel diambil dengan metode purposive sampling yaitu pemilihan sampel berdasarkan karakteristik yang sudah ditentukan. Adapun karakteristik yang harus dipenuhi oleh sampel antara lain :

1. Perbankan tersebut merupakan Bank Umum Syariah (BUS) yang terdaftar dalam Bank Indonesia selama masa penelitian.

2. Perbankan tersebut secara teratur mempublikasi laporan keuangan perusahaannya dengan lengkap dan jelas.

3. Pada laporan keuangan bank tersebut terdapat variabel-variabel yang digunakan untuk menunjang penelitian.

Berdasarkan kriteria yang telah ditentukan terdapat 7 BUS yang digunakan dalam penelitian yaitu Bank Negara Indonesia Syariah, Bank Syariah Mandiri, Bank Rakyat Indonesia Syariah, Bank Muamalat Indonesia, Bank Central Asia Syariah, Bank Mega Syariah, dan Bank Bukopin Syariah. Sumber data sekunder diperoleh dari laporan keuangan yang telah dipublikasikan dilaman resmi masing-masing bank. Alat uji statistik untuk menjawab hipotesis penelitian menggunakan program Eviews 9.0. Penelitian ini menggunakan regresi linier data panel sebagai tekhnik analisis data. Penelitian ini menggunakan regresi data panel karena data yang digunakan merupakan gabungan antara cross section dan time serries. Selanjutnya, dilakukan uji asumsi klasik dan Uji Hipotesis menggunakan diantaranya uji-t, uji-f dan uji-r square.

\section{Hasil dan Pembahasan \\ Hasil Uji Asumsi Klasik}

\section{Uji Normalitas}


142 | Annisa Millania, et.al, PENGARUH BOPO, NPF, ROA DAN INFLASI TERHADAP ASET.......

Uji normalitas dilakukan untuk menguji apakah antar variabel dependen dan variabel independen dapat terdistribusi normal atau tidak normal. Uji normalitas dilakukan dengan metode Jarque-Bera. Data dikatakan normal jika memiliki data normal atau mendekati normal. Adapun nilai kenormalan dari data yaitu lebih besar dari 0.05 .

Figure 1. Uji Normalitas

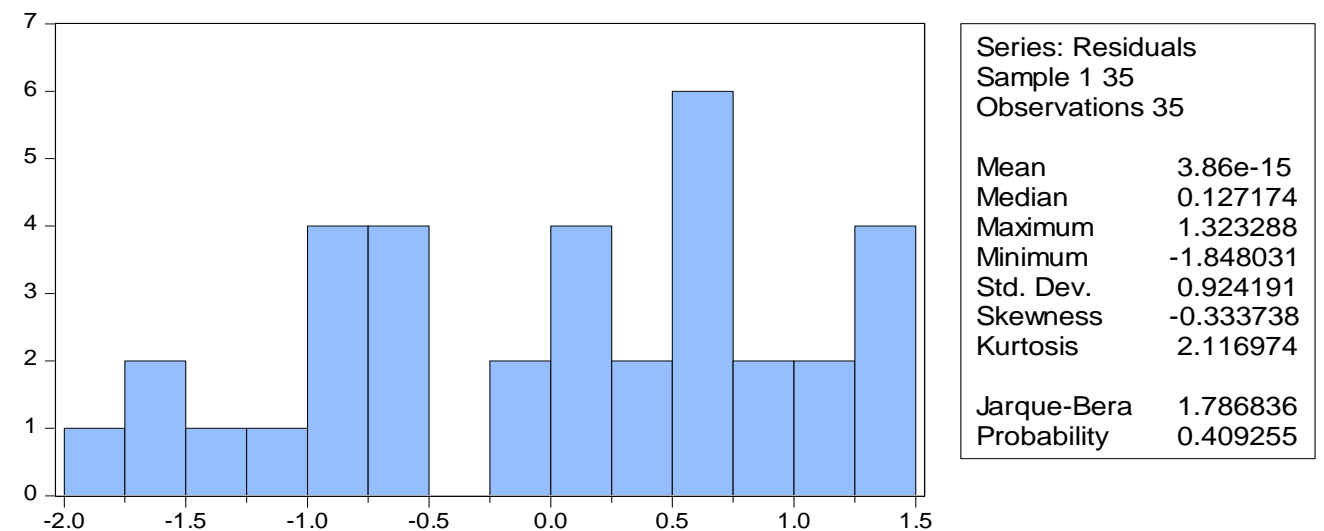

sumber : data diolah (Eviews 9.0)

Berdasarkan pada grafik terebut probability data sebesar $0.409255>0.05$. maka dapat disimpulkan bahwa data berdistribusi normal. Dengan demikian, asumsi persyaratan normalitas dalam model regresi telah terpenuhi.

\section{Uji Autokorelasi}

Uji ini ditujukan unutk melihat apakah terdapat korelasi antara satu periode dengan periode sebelumnya.

Tabel 2

Hasil Uji Autokorelasi

\begin{tabular}{llll}
\hline F-statistic & 7.966840 & Durbin-Watson stat & 1.339100 \\
\hline Prob(F-statistic) & 0.000045 & &
\end{tabular}

Sumber : data diolah (Eviews 9.0)

Berdasarkan tabel 2 dapat dilihat Durbin-Watson 1.339.100 yang mana nilai Probabiltas sebesar 0.000045. maka dapat disimpulkan bahwa tidak terdapat masalah atau gejala autokorelasi.

\section{Hasil Uji Hipotesis}


ISLAMIC BANKING: Jurnal Pemikiran dan Pengembangan Perbankan Syariah, Volume 7 Nomor 1 Edisi Agustus 2021

Berdasarkan uji hipotesis terhadap masing-masing data diperoleh model dari penelitian yaitu Random Effect Model. Uji T ditujukan untuk melihat pengaruh parsial dari tiap variabel dependen terhadap variabel independen. Sementara Uji F digunakan untuk melihat pengaruh simultan dari variabel dependen terhadap variabel independen.

Tabel 3. Hasil Uji t

\begin{tabular}{llll}
\hline Variabel & Koefisien & Probabilitas & Keterangan \\
\hline Inflasi & -0.244330 & 0.0328 & Signifikan \\
BOPO & -0.027106 & 0.0372 & Signifikan \\
NPF & 0.042066 & 0.2778 & Tidak signifikan \\
ROA & -0.095809 & 0.3119 & Tidak signifikan \\
\hline
\end{tabular}

Sumber : data diolah dengan Eviews 9.0

\section{Pengaruh Inflasi Terhadap Pertumbuhan Aset perbankan syariah}

Berdasarkan Tabel 3 dinyatakan bahwa variabel inflasi berpengaruh negatif dan signifikan terhadap aset perbankan syariah. Pengaruh signifikan inflasi terhadap aset perbankan syariah menunjukkan bahwa bank syariah juga terkena dampak dari gejolak inflasi. Sedangkan pengaruh negatif inflasi terhadap aset perbankan syariah dapat diartikan bahwa semakin tingginya tingkat inflasi justru akan menyebabkan menurunnya tingkat pertumbuhan aset bank syariah.

\section{Pengaruh BOPO Terhadap Pertumbuhan Aset perbankan syariah}

Pada variabel BOPO berpengaruh negatif dan signifikan terhadap aset perbankan syariah. BOPO berpengaruh signikfikan yang berarti tingkat efisiensi oprasional bank mempengaruhi jumlah aset yang dimiliki oleh bank. Sedangkan pengaruh negatif BOPO terhadap aset perbankan syariah diartikan bahwa semakin tingginya nilai tingkat BOPO pada perbankan syariah justru akan menurunkan tingkat pertumbuhan aset yang dicapainya karena biaya operasional pada bank semakin tinggi atau pendapatan operasionalnya yang justru semakin rendah. Artinya semakin tinggi nilai BOPO pada bank menunjukkan bahwa operasional bank semakin tidak efisien. 


\section{Pengaruh NPF Terhadap Pertumbuhan Aset perbankan syariah}

Variabel NPF berpengaruh positif dan tidak signifikan terhadap aset perbankan syariah. Artinya, pembiayaan bermasalah pada perbankan syariah tidak berpengaruh secara signifikan terhadap aset perbankan syariah. Meskipun demikian, NPF yang tinggi akan memberikan dampak signifikan terhadap pos lain, karena menurunnya produktivitas keuntungan bank syariah.

\section{Pengaruh ROA Terhadap Pertumbuhan Aset perbankan syariah}

Variabel ROA berpengaruh negatif dan tidak signifikan terhadap aset perbankan syariah. Pengaruh signifikan ini mengindikasikan bahwa tingkat keuntungan yang diperoleh perbankan syariah memiliki sumbangan yang cukup besar terhadap total aset yang dihimpunnya. Pengaruh negatif ROA terhadap aset perbankan syariah di Indonesia mengindikasikan bahwa tingkat nilai ROA yang cenderung fluktuatif selama periode penelitian berdampak pada menurunnya pertumbuhan aset perbankan syariah. Dengan menurunnya nilai pertumbuhan ROA perbankan syariah minat masyarakat untuk menabungkan uangnya pada bank syariah juga menurun akibat return bagi hasil kepada masyarakat yang semakin rendah.

\section{Tabel 4. Hasil Uji F Dengan Random Efect Model}

\begin{tabular}{llll}
\hline \hline & & & \\
R-squared & 0.207003 & Mean dependent var & 2.590198 \\
Adjusted R-squared & 0.101270 & S.D. dependent var & 0.217099 \\
S.E. of regression & 0.205812 & Sum squared resid & 1.270763 \\
F-statistic & 1.957790 & Durbin-Watson stat & 0.743068 \\
Prob(F-statistic) & 0.126588 & & \\
\hline
\end{tabular}

Tabel hasil uji F menggambarkan nilai probabilitas (F-Statistic) sebesar 0.126588, yang mana nilai tersebut lebih besar dari 0.05. Hal demikian, dapat disimpulkan bahwa secara simultan seluruh variabel independen tidak berpengaruh terhadap variable dependen. Sedangkan kontribusi antar variabel menggambarkan besarnya angka koefisien determinasi adalah 0,207 atau sama dengan 20,7\%. Dengan demikian, variabel inflasi, NPF, BOPO, ROA berpengaruh terhadap pertumbuhan aset bank syariah sebesar 20,7\%. Sedangkan 79,3\% dipengaruhi oleh variabel-variabel lain. 


\section{Simpulan}

Berdasarkan temuan penelitian ini menunjukkan bahwa inflasi dan BOPO memiliki pengaruh terhadap aset perbankan syariah. sedangkan, NPF dan ROA tidak berpengaruh terhadap Aset perbankan syariah. Penelitian selanjutnya diharapkan menambahkan variabel makro seperti GDP dan menambahkan tahun observasi agar mendapatkan hasil yang lebih refresentatif.

\section{DAFTAR PUSTAKA}

Akbar, dinnul alfian. 2016. 'Inflasi, Gross Domestic Product (GDP), Capital Adequacy Ratio (CAR), Dan Finance To Deposit Ratio (FDR) Terhadap Non Perfoming Financing (NPF) Pada Bank Umum Syariah Di Indonesia'. I-Economic 2(2): 1937.

Alawiyah, Syifa. 2019. 'Pengaruh Non Perfoming Financing (NPF), Return Of Assets (ROA), Dan Pembiayaan Terhadap Pertumbuhan Aset Bank Umum Syariah Di Indonesia Tahun 2014-2018'. Universitas Islam Negeri Syarif Hidayatullah. . 2019b. 'Pengaruh Non Performing Financing (NPF), Financing to Deposit Ratio (FDR), Return On Assets (ROA), dan pembiayaan terhadap pertumbuhan aset bank umum syariah di indonesia tahun 2014-2018'. universitas islam negeri syarif hidayatullah.

Ardana, Yudhistira. 2018. 'Faktor Eksternal Dan Internal Yang Mempengaruhi Profitabilitas Bank Syariah Di Indonesia'. Cakrawala 13(1): 51.

Argarina, and Kamaliah. 2016. 'Analisis Perbandingan Kinerja Keuangan Bank Syariah Dengan BBank Konvensional Di Indonesia'. Jurnal Tepak Manajemen Bisnis 3 VIII(3): 1-19.

Ayif Fathurrahman, Maya Kumala Sari. 2020. 'Determinant Of Total Assets Of Sharia Banks In Indonesia (An Error Correction Model Approach)'. Amwaluna: Jurnal Ekonomi dan Keuangan Syariah 4(2): 300-310.

Bakti, Nurimansyah Setivia. 2017. 'Analisis Dpk, Car, Roa Dan Npf Terhadap Pembiayaan Pada Perbankan Syariah'. Jurnal Bisnis dan Manajemen 17(2): 1528.

Caglayan, Mustafa, and Bing Xu. 2016. 'Inflation Volatility Effects on the Allocation of Bank Loans'. Journal of Financial Stability 24: 27-39.

Chou, Te-Kuang, and Agung Dharmawan Buchdadi. 2016. 'Bank Performance and Its Underlying Factors: A Study of Rural Banks in Indonesia'. Accounting and Finance Research 5(3): 55-63.

Dalimunthe, Ibram Pinondang, and Ajeng Desni Lestari. 2019. 'Effect of Inflation and Price Index on Equity Assets'. Eaj (Economics and Accounting Journal) 2(1): 42. 
Datta, Chandan Kumer, and Abdullah Al Mahmud. 2018. 'Impact of Capital Adequacy on Profitability Under Basel II Accord: Evidence from Commercial Banks of Bangladesh'. European Journal of Business and Management 10(8): 48-58. www.iiste.org.

Dhiba, Nadhiera Ahya, and Lavlimatria Esya. 2019. 'Pengaruh NPF, BOPO, GDP, Dan SBIS Terhadap Pertumbuhan Aset Perbankan Syariah DiIndonesia'. Media Ekonomi 27(1): 9-16.

Hijriyani, nuri zulfah, and Setiawan. 2017. 'Analisis Profitabilitas Perbankan Syariah Di Indonesia Sebagai Dampak Dari Efisiensi Operasional'. Jurnal Kajian Akuntansi, 1(2): 194-209.

Indura, Alif Chandra, and Abdul Aziz Ahmad. 2019. 'Analisis Faktor Internal Dan Eksternal Yang Mempengaruhi Pertumbuhan Aset Bank SSyariah Di Indonesia'. IJIBE : Indonesia Journal of Islamic Businenn and Economics 01: 1-55.

Koto, Dini Ayu Amanda. 2020. 'Pengaruh Inflasi, Non Perfoming Finance (NPF), Return On Asset (ROA) Terhadap Pertumbuhan Aset BPRS Di Indonesia'. Universitas Islam Negeri Sumatra Utara.

Mawardi, Diamantin Rohadatul Aisy dan Imron. 2016. 'Faktor - Faktor Yang Mempengaruhi Pertumbuhan Aset Bank Syariah Di Indonesia Tahun 20062015'. Jurnal Ekonomi Syariah Teori dan Terapan 3(3): 249-65.

Megasuri, Carissa Sridevi, and Shinta Permata Sari. 2018. Faktor-Faktor Eksternal Yang Mempengaruhi Pertumbuhan Aset Bank Umum Syariah Di Indonesia Selama Satu Dasawarsa ( 2009-2018).

Oktavianti, Elda, and Satria Tri Nanda. 2019. 'Analisis Pengaruh CAR, NPF, BOPO, Inflasi, Produk Domestik Bruto Dan Suku Bunga BI Terhadap Pertumbuhan Perbankan Syariah'. Ilmiah Ekonomi Dan Bisnis 16(1): 46-55.

Puji Wiyati , M. Yusuf, Tutut Dwi Andayani. 2016. 'Faktor-Faktor Yang Mempengaruhi Profitabilitas Lembaga Keuangan Mikro Syariah (LKMS) (Studi Pada Btm Se Kabupaten Pekalongan)'. Majalah Neraca.

Raharjo, Hendrawan et al. 2020. 'Inflasi Terhadap Profitabilitas Bank Umum Syariah Di Indonesia ( Tahun 2014-2018 )'. Jurnal Ilmiah Akuntansi dan Manajemen (JIAM) 16(1): 15-26.

Said, Muhammad, and Herni Ali. 2016. 'An Analysis on the Factors Affecting Profitability Level of Sharia Banking in Indonesia'. Banks and Bank Systems 11(3): 28-36.

Shandy Utama, Andrew. 2018. 'Sejarah Dan Perkembangan Regulasi Mengenai Perbankan Syariah Dalam Sistem Hukum Nasional Di Indonesia'. Jurnal Wawasan Yuridika 2(2): 187-200.

Sofie, Mohammad, Adler Haymans Manurung, Bahtiar Usman, and Universitas Trisakti. 2020. 'Determinants of Bank Profitability with Size as Moderating Variable'. Journal of Applied Finance \& Banking 10(March): 1792-6599. https://www.researchgate.net/publication/339434242.

Supriani, Indri, and Heri Sudarsono. 2018. 'Analisis Pengaruh Variabel Mikro Dan Makro Terhadap NPF Perbankan Syariah Di Indonesia'. EQUILIBRIUM: Jurnal Ekonomi Syariah 6(1): 1-18.

Syah, Toufan Aldian. 2018. 'Pengaruh Inflasi, BI Rate, NPF, Dan BOPO Terhadap 
Profitabilitas Bank Umum Syariah Di Indonesia'. El-Jizya: Jurnal Ekonomi Islam 6(1): 133-53.

Tolulope, Apanisile Olumuyiwa, and Oyelami Lukman Oyeyinka. 2014. 'The Impact of Inflation on Financial Sector Performance: A Case Study of Sub-Saharan Africa'. Indian Journal of Finance 8(1): 43-50.

Tri Wahyuningsih, Abrar Oemar, Agus Suprijanto. 2017. 'Pengaruh CAR, NPF, FDR, BOPO, dan GWM Terhadap Laba Perusahaan (ROA) Pada Bank Umum Syariah Di Indonesia Periode 2010-2015'. Journal Of Accounting.

Undang - Undang RI, Bank Indonesia. 1998. 'Undang-Undang Republik Indonesia Nomor 7 Tahun 1992 Tentang Perbankan Sebagaimana Telah Diubah Dengan Undang-Undang Nomor 10 Tahun 1998'. Bank Indonesia: 1-65.

Vanni, Kartika Marella, and Wahibur Rokhman. 2017. 'Analisis Faktor-Faktor Yang Mempengaruhi Non Performing Financing Pada Perbankan Syariah Di Indonesia Tahun 2011-2016'. EQUILIBRIUM : Jurnal Ekonomi Syariah 5(2): 306-19.

Wahyudi, Rofiul. 2020. 'Analisis Pengaruh CAR, NPF, FDR, BOPO Dan Inflasi Terhadap Profitabilitas Perbankan Syariah Di Indonesia: Studi Masa Pandemi Covid-19'. At-Taqaddum 12(1): 13.

wasiaturrahma et al. 2020. 'Heliyon Breadth and Depth Outreach of Islamic Cooperatives : Do Size, Non-Performing Fi Nance, and Grant Matter?'Heliyon 6(January): e04472.

Yundi, Nisa Friskana. 2018. 'Pengaruh Kinerja Keuangan Terhadap Return On Ssset ( ROA ) Bank Syariah Di Indonesia'. Al-Amwal 10(1): 18-31. 
148 | Annisa Millania, et.al, PENGARUH BOPO, NPF, ROA DAN INFLASI TERHADAP ASET....... 